\title{
A Brief Analysis of Cultural Colonialism
}

\author{
Yang Zhao \\ Foreign Languages College, Beihua University, Jilin 132013, China.
}

Keywords: hegemony, postcolonialism, imperialism

\begin{abstract}
Culture, like history, is an expanding and developing phenomenon. It means that culture is not a kind of static phenomenon; it would change with the society, even with the politics.
\end{abstract}

\section{Introduction}

As a branch of cultural theories, postcolonialism refers to a collection of theoretical and critical strategies used to examine culture of former colonies of the European empires, and their relation to the rest of the world. That is, after the end of World War II, Western colonists withdrew from former colonies, some of which have been controlling, dominating and permeating by them from economy to culture. If the early colonists use violent force, there appears to be "gentle style" for postcolonists. Postcolonial studies pay much attention to the problem of culture, which is inspired by Gramsci. In Gramsci's opinion, the notion of culture includes both the contents of philosophy and all forms of literary art. Gramsci combines the social function of literary art and ideology together, and considers culture as the core of ideological theory.

\section{Culture and Hegemony}

Gramsci considers culture, including literary art, as the hidden style of government compared with the apparatus of state, some social groups therefore get the leadership in thoughts, ideology, culture, morality under some social formation, which Gramsci calls cultural hegemony. In his opinion, capitalist country is composed of 'political society' and 'civil society'. Forms of state power of political society appear to be direct ruling, depending on military, policemen and prisons. Forms of state power of civil society appear to be leadership completed by families, schools, churches and media. Different from Hegel and Marx, Gramsci considers civil society as part of superstructure, not the economic base. In western countries, the ruling of bourgeoisie does not mainly depend on political society and its deputies; it mainly depends on the controlling to ideology, by controlling civil society, then makes the public accept some moral concepts, value systems. The apparatus of state is easily destroyed, while the complex civil society is hard to break. Once the control of culture and ideology weakens, the state will be in danger. We can see Gramsci emphasizes on the function of ideology, that is, dominant groups make the great masses of the population subordinate present political and social order by the way of culture.

In Orientalism, Said uses “Orientalism” to describe postcolonial relationship of the West and the East. In his opinion, 'the Orient' and 'the Occident' are not specific definitions of geographical position; they are a kind of cultural phenomenon. "The Orient was almost a European invention, and had been since antiquity a place of romance, exotic beings, haunting, memories and landscapes, remarkable experiences." From the relations between discourse and power, Said points out how culture of British colonialism has an effect on the discourse of Oriental culture in the form of power, how to extend power of colonialism by colonized discourse; on the other hand, he shows how cultural centralism of Europe constructs Oriental images, how to form so-called laziness, lie and irrationality of the Orient in the Western countries by discourse. Cultural strength is not something we can discuss very easily, and as Said says "one of the purposes of the present work (Orientalism) is to illustrate, analyze, and reflect upon Orientalism as an exercise of cultural strength". Here we should know, Said warns us not to look down upon the function of culture or cultural strength, and Orientalism is a way of cultural colonialism.

In his Orientalism and Culture and Imperialism, Said has emphasized what in a rather general 
way he had called "culture". The word is written with a quotation, we can see it is different. As Said uses this word, his culture has two meaning in particular: first of all it means all those practices, like the arts of description, communication, and representation, that have relative autonomy from the economic, social, and political realms and that often exist in aesthetic forms, one of whose principal aims is pleasure. Included, of course are both the popular stock of lore about distant parts of the world and specialized knowledge available in such learned disciplines as ethnography, historiography, philosophy, sociology, and literary history. While Said pays much attention to cultural forms like the novel, he believes that the novel was particularly important in the formation of imperial attitudes, references, and experiences. He doesn't mean that only the novel was important, he considers it the aesthetic object whose connection to the old colonizers of Britain and France is interesting to study. As we know, the prototypical modern realistic novel is Robinson Crusoe, and certainly not accidentally it is about a European who creates a fiefdom for himself on a distant, non-European island.

Gramsci formulates his concept of 'hegemony'. Hegemony is power achieved through a combination of coercion and consent. Playing upon Machiavelli's suggestion that power can be achieved through both force and fraud, Gramsci argues that the ruling class achieves domination not by force or coercion alone, but also by creating subjects who 'willingly' submit to being ruled. Ideology is crucial in creating consent, it is the medium through which certain ideas are transmitted and more important, held to be true. Hegemony is achieved not only by direct manipulation or indoctrination, but by playing upon the common sense of people, upon what Raymond Williams calls their 'lived system of meanings and values'. Said's Orientalism stresses on the notion of power and ideology. The power of the Orientalism is a kind of knowledge power, while knowledge is a branch of culture, the power means cultural power. Said borrows the notion of hegemony from Gramsci, as he says "In any society not totalitarian, then, certain cultural forms predominate over others, just as certain ideas are more influential than others; the form of this cultural leadership is what Gramsci has identified as hegemony, an indispensable concept for any understanding of cultural life in the industrial West. It is hegemony or rather the result of cultural hegemony at work, which gives Orientalism the durability and the strength I have been speaking about so far". Hegemony comes from Gramsci who concentrates on the complex connections among the state, society, and culture instead of industrial working class and its 'historical mission', thereby providing a different framework to articulate revolutionary tactics. For Gramsci, hegemony consists of political power that flows from intellectual and moral leadership, authority or consensus, as distinguished from mere armed force. Bocock, in his analysis of hegemony stresses that a major component in Gramsci's theory is the capacity of the dominant group (the ruling class or alliance of classes, or class fractions) to provide intellectual, moral, and philosophical leadership and to pursue policies which are not in the direct, narrow interest of capitalists but rather which can be presented plausibly as being in the interests of the whole people, of the nation. Therefore, Said uses the specific notion of hegemony instead of the general notion of power from Foucault.

\section{Cultural Colonialism}

As we know, colonialism refers to direct ruling by colonists on the politics and military before World War II, neo-colonialism means indirect ruling on economy by former colonists after World War II, especially after the Cold War. If colonialism and neo-colonialism focus on political and economic relationship between the metropolitan state and the colonized countries, postcolonialism pays much attention to cultural relationship between them, that is, postcolonialism emphasizes cultural problem. So postcolonialism is also called cultural colonialism. Another Said's contribution is to find the relationship between imperialism and culture. He re-construes classical works of the British and French novelists in order to explain "imperialism and the novel fortified each other to such a degree that it is impossible, to read one without in some way dealing with the other". According to Said, many Western critical theories evaded the problem that how metropolitan society, culture and ideology are constructed by imperialism. People always ignore the role culture plays in the development of empire. A radical falsification has become established in this separation. Culture 
is exonerated of any entanglements with power, representations are considered only as apolitical images to be parsed and constructured as so many grammars of exchange. And yet, far from this separation of spheres being a neutral or accidental choice, its real meaning is as an act of complicity, the humanist's choice of a disguised, denuded, systematically purged textual model over a more embattled model, whose principal features would inevitably coalesce around the continuing struggle over the question of empire itself.

Said teaches us to read novels keeping to the stand of postcolonial theory, that is combining the novel texts and the background of imperialism together. By this method, we could understand tiny points of the novels thoroughly. In Jane Austen's Mansfield Park, Sir Thomas Bertram's estate which seems to be sheltered in its English provincialism is propped up by Antiguan sugar plantations which were run by slave labor. In Jane Eyre, Rochester's mad wife - Mason is not only a West Indian, but also a danger existence imprisoned in the attic. 'Mad' first wife, who is burnt to death, clears the way for Jane's marriage to Mr. Rochester. Bertha's madness is the misery and oppression of a white Creole woman married for her plantation wealth, then dislocated from her island home in the Caribbean and locked up in an English manor. Sedley in Thackeray's Vanity Fair, this vulgar local governor in India has millions of money which makes us doubt. In Dickens' many novels, the businessmen have related with empire, such as Dombey. At the end of Hard Times, Tom goes to the colony by sea. For Said, only by understanding empire, overseas expansion and colonization, we can read British novels thoroughly and the inner spirits could appear. Before the middle of $19^{\text {th }}$ century, empire and colonization in novels hid sometimes, after that, both of them became the themes of Kipling's, Conrad's works. The consciousness of empire in Britain novels is in the process of being hidden to appear. By exploring British novels, the representative of European novels, Said concludes that, European novels in $19^{\text {th }}$ century are a kind of cultural form emphasizing power. In each novel, overseas experience expresses and reflects the relationship of local authorities and the overseas.

\section{Summary}

From above all, the job facing the cultural intellectual is therefore not to accept the politics of identity as given, but to show how all representations are constructed, for what purpose, by whom, and with what components, which is far from easy. In Fanon's The Wretched of the Earth, his opinion was that unless national consciousness at its moment of success was somehow changed into a social consciousness, the future would hold not liberation but an extension of imperialism. Said found a new kind of humanism from Fanon's notion- a large cultural turning point from nationalism to the theoretical domain of liberation. According to Said, this turning point was a key one, “... we must strive to liberate all mankind from imperialism; we must all write our histories and cultures prescriptively in a new way; we share the same history, even though for some of us that history has enslaved. This, in short, is writing from the colonies coterminous with the real potential of post-colonial liberation".

\section{References}

[1] Said, E.W. Culture and Imperialism, Alfred A. Knopf, 1994.

[2] Bocock, R. Hegemony. Ellis Horwood and Tavistock, 1986.

[3] Anderson, Benedict. Imagined Communities: Reflections on the Origin and Spread of Nationalism, Verso, 1991.

[4] Viswanathan,G. Masks of Conques: Literary Studies \& British Rule in India. Faber, 1990.

[5] Said, Edward W. Orientalism. Routledge and Kagan Paul, 1978. 